\title{
INFLUENCE OF ABIOTIC FACTORS ON GROWTH AND DEVELOPMENT OF GIANT BAMBOO (DENDROCALAMUS ASPER) IN BUKIDNON, PHILIPPINES
}

\author{
Aribal LG' ${ }^{1}$, Parlucha JA ${ }^{2, *}$, Gelaga $\mathrm{JN}^{1}$ \& Aguinsatan RG $^{3}$ \\ ${ }^{1}$ Department of Forest Biological Science, College of Forestry and Environmental Science, Central Mindanao University, \\ Bukidnon, Philippines \\ ${ }^{2}$ Department of Wood Science and Technology, College of Forestry and Environmental Science, Central Mindanao \\ University, Bukidnon, Philippines \\ ${ }^{3}$ Department Forest Resource Management, College of Forestry and Environmental Science, Central Mindanao \\ University, Bukidnon, Philippines
}

*parluchajason@cmu.edu.ph

Submitted December 2020; accepted February 2021

\begin{abstract}
The study examines the gross morphology of giant bamboo (Dendrocalamus asper) relative to varying elevation, temperature, and relative humidity in five forest areas of Bukidnon province in the Philippines. Results revealed that variations in leaf sizes and the number of nodes and internodes among elevation ranges were not significant. However, the culm length of giant bamboo was significantly higher in the mid-elevation range (644-892 $\mathrm{m}$ asl) and lower elevation range (344-447 m asl) compared to culms in higher elevations. In addition, differences in culm diameter and culm thickness were significant showing larger diameter and thicker culms in the mid-elevation range (644-892 $\mathrm{m}$ asl) as compared to the higher (1117-1124 m asl) and lower (344-347 $\mathrm{m}$ asl) elevation range. The level of phosphorus and nitrogen was the highest in the mid and lower elevation range while potassium level was abundant in the highest elevations. Correlation analysis showed a negative relationship between culm lengths to elevation and relative humidity while mid and top section diameters were negatively correlated to temperature until $892 \mathrm{~m}$ asl. Leaf area and leaf width were strongly influenced by phosphorus level. The canonical correspondence analysis showed culm lengths were affected by relative humidity and elevation while the number of nodes and internodes, top and mid-section culm thickness, average diameter and basal section diameters were affected by temperature. Non-metric multidimensional scaling revealed that variation in bamboo morphology occured at the lowest and highest elevation while overall similarity was observed at 600-900 m asl elevation, suggesting an optimal growth for giant bamboo might be within the range.
\end{abstract}

Keywords: Tropical rain forest, species richness, tropical biodiversity

\section{INTRODUCTION}

The numerous use of bamboo is gaining wide acceptance as the best substitute material due to the limited supply and high cost of wood and wood products as a result of unfavorable policies and regulations affecting wood industries in the Philippines (Pulhin and Ramirez 2016). Bamboo is considered among the most important non-timber forest products in the country from its total production and export gain (Razal and Palijon 2009). Various household and light construction applications were produced at a minimal cost using bamboo and hence regarded as poor man's timber. In Bukidnon province, giant bamboo (Dendrocalamus asper) is a highly utilised and among the most economically important species of bamboo (Decipulo et al. 2009). Its culms are used as tomato plant stakes, poultry floors, bamboo shoot production, and in furniture industry as engineered bamboo which is gaining more prominence as a replacement for timber. Moreover, the demands of giant bamboo seedlings for forest restoration purposes continuously provide significant contributions in generating livelihood and rural employment in the region (Decipulo et al. 2009). In fact, bamboo was included among the high priority species to be used for the national greening program of the Philippine 
government (Aguinsatan et al. 2019). However, areas solely intended for bamboo plantations are limited because agricultural production is of high priority and constitutes much of the land-use. Generally, sources of culms are seldom in pure stands but from the naturally grown stands, in backyards, from patches to demarcate boundaries of farm lots, in riverbanks, marginal areas, and areas where agriculture is not feasible (Midmore 2009). These natural bamboo stands received no care and maintenance because they are treated as grass and can thrive ubiquitously. Therefore, silvicultural treatments and stand management interventions while observing the species ecophysiology in planting is not a common norm.

Plants alter their development, physiology and life history depending on the environmental conditions (Gratani 2014) and is referred as phenotypic plasticity. It is nearly ubiquitous and occurs in various animals and plants as expressed in their behavior, physiology and morphology. Phenotypic plasticity may be observed as adaptive and non-adaptive responses to the biotic or abiotic environments (Mooney \& Agrawal 2008). Hence, environmental factors such as light, temperature, water and soil greatly influence plant growth. The study intended to evaluate the gross morphology of giant bamboo relative to different site conditions. The responses in the morphological structure would provide basic information to determine the influence of the abiotic factors on the growth and development of the plant including their physical and mechanical properties of the material. Optimal bamboo growth and suitability of the site could potentially become a basic guide to identify the ideal sites for growing giant bamboo and improving the productivity of bamboo farms in the area.

\section{MATERIALS AND METHODS}

\section{Study site}

Five areas in Bukidnon province in Mindanao, Philippines with different elevations were randomly selected as sampling sites (Figure $1)$. The lowest elevation ranges from 345 to $347 \mathrm{~m}$ asl while the highest elevation ranges from 1117 to $1124 \mathrm{~m}$ asl (Table 1 ). The climate condition of the area had no pronounced seasonal variability with dry season during November to April and wet season in the remaining months of the year (Parlucha et al. 2017). Selected bamboo stands were situated in bamboo dominated riparian zones with flat to undulating terrains.

\section{Sample collection and measurements}

Samples collected were from the bamboo stands ages from 3-5 years old and located at least 30 meters from any water bodies including in riparian areas. The stands were geotagged to determine their elevation. A total of 9 poles with 3 poles from different clumps per stand aging 4 years old were collected per sampling site. Every bamboo pole collected was subdivided into three sections such as basal, mid and top. The culm length was measured using metric tape while the culm wall thickness was measured using digital caliper. The measurement was replicated 8 times and an average reading was taken for the lower side and upper side of the sectioned culm. The diameters of each section were also measured using tree caliper while the number

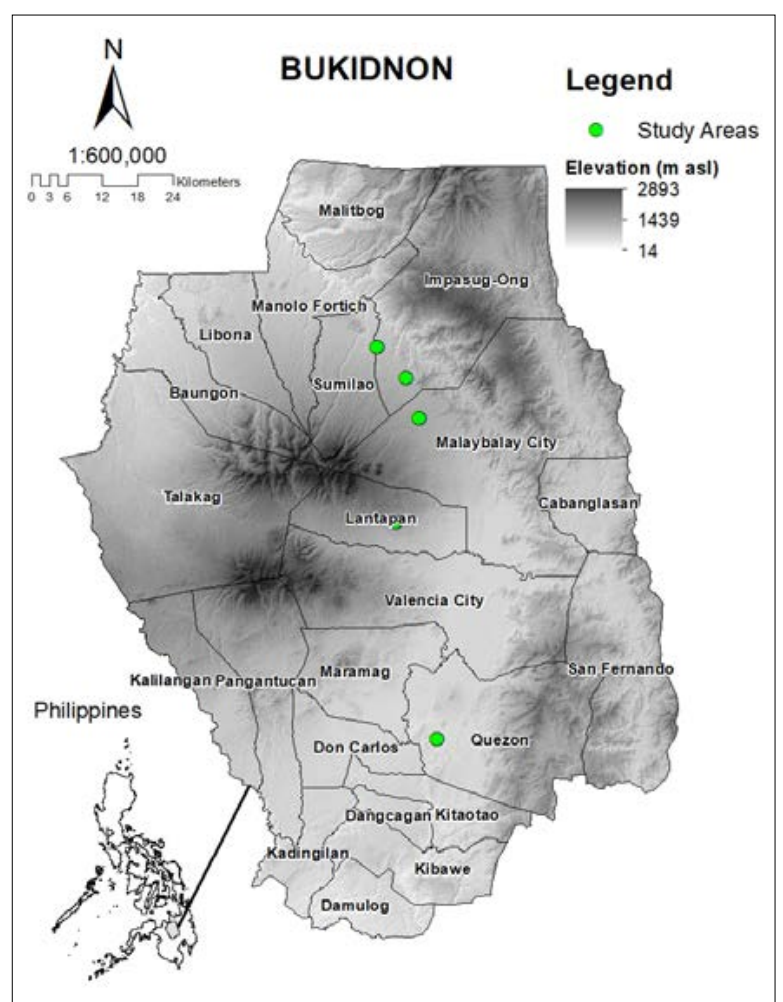

Figure 1 Location of the study area 
Table 1 The geographic coordinates and elevations of the sampling sites

\begin{tabular}{|c|c|c|c|}
\hline Location & Sample & Coordinates & Elevation ( $\mathrm{m}$ asl) \\
\hline \multirow[t]{3}{*}{1} & 1 & $7^{\circ} 42^{\prime} 17.0^{\prime \prime} \mathrm{N} 125^{\circ} 04^{\prime} 25.0^{\prime \prime} \mathrm{E}$ & 345 \\
\hline & 2 & $7^{\circ} 42^{\prime} 17.0 ” \mathrm{~N} 125^{\circ} 04^{\prime} 25.0 ” \mathrm{E}$ & 344 \\
\hline & 3 & $7^{\circ} 42^{\prime} 17.0 ” \mathrm{~N} 125^{\circ} 04^{\prime} 25.0^{\prime \prime} \mathrm{E}$ & 347 \\
\hline \multirow[t]{3}{*}{2} & 1 & $8^{\circ} 18^{\prime} 25.0 ” \mathrm{~N} 124^{\circ} 59^{\prime} 03.5 ” \mathrm{E}$ & 651 \\
\hline & 2 & $8^{\circ} 18^{\prime} 25.9 ” \mathrm{~N} 124^{\circ} 59^{\prime} 03.5 ” \mathrm{E}$ & 650 \\
\hline & 3 & $8^{\circ} 18^{\prime} 25.9 ” \mathrm{~N} 124^{\circ} 59^{\prime} 02.9^{\prime \prime E}$ & 644 \\
\hline \multirow[t]{3}{*}{3} & 1 & $8^{\circ} 18^{\prime} 25.9 ” \mathrm{~N} 124^{\circ} 59^{\prime} 02.9^{\prime \prime} \mathrm{E}$ & 777 \\
\hline & 2 & $8^{\circ} 15^{\prime} 30.3 ” \mathrm{~N} 125^{\circ} 01^{\prime} 47.0^{\prime \prime} \mathrm{E}$ & 770 \\
\hline & 3 & $8^{\circ} 15^{\prime} 30.3 ” \mathrm{~N} 125^{\circ} 01^{\prime} 47.0 ” \mathrm{E}$ & 765 \\
\hline \multirow[t]{3}{*}{4} & 1 & $8^{\circ} 11^{\prime} 49.1 ” \mathrm{~N} 125^{\circ} 02^{\prime} 56.9 ” \mathrm{E}$ & 890 \\
\hline & 2 & $8^{\circ} 11^{\prime} 49.1 ” \mathrm{~N} 125^{\circ} 02^{\prime} 56.9 ” \mathrm{E}$ & 890 \\
\hline & 3 & $8^{\circ} 11^{\prime} 49.5 ” \mathrm{~N} 125^{\circ} 02^{\prime} 56.2 ” \mathrm{E}$ & 892 \\
\hline \multirow[t]{3}{*}{5} & 1 & $8^{\circ} 02^{\prime} 18.0 ” \mathrm{~N} 125^{\circ} 00^{\prime} 46.0 ” \mathrm{E}$ & 1117 \\
\hline & 2 & $8^{\circ} 02^{\prime} 18.0 ” \mathrm{~N} 125^{\circ} 00^{\prime} 46.0 ” \mathrm{E}$ & 1120 \\
\hline & 3 & $8^{\circ} 02^{\prime} 18.0 ” \mathrm{~N} 125^{\circ} 00^{\prime} 46.0^{\prime \prime} \mathrm{E}$ & 1124 \\
\hline
\end{tabular}

of nodes and internodes for each culm were counted manually.

A data logger was installed in every sampling site and positioned at 5 meters height from the ground within the bamboo stand to measure the daily fluctuations of temperature and relative humidity. Their averages were used to infer the relationship via correlation analysis.

\section{Sample measurements}

At least fifty fresh leaves were randomly collected in every bamboo stand from freshly cut bamboo poles. The leaf size indices consisted of length and width were measured using a caliper. The leaf area was determined using the following formula (Cain \& De Castro 1959).

$$
\text { Leaf area }=2 / 3 \mathrm{LW}
$$

where,

$\mathrm{L}=$ Leaf length measured from the base to the apex

$\mathrm{W}=$ Leaf width measured at the edge of the widest portion

Composite leaf samples of every sampling site were collected following standard leaf sampling protocol (Pond et al. 2006). Samples were stored in a sealed container and sent to soil and plant analysis laboratory to determine the nitrogen $(\mathrm{N})$, phosphorus $(\mathrm{P})$ and potassium (K) uptake of each bamboo stand.

\section{Statistical analysis}

One-way Analysis of Variance (ANOVA) and Pearson correlation analysis was performed in SPSS package Version 17.0 for Windows. Tukey's Honest Significant Difference (HSD) was used for post-hoc analysis. The Canonical Correspondence Analysis (CCA) and Nonmetric Multidimensional Scaling (NMDS) were processed in PAST Software.

\section{RESULTS AND DISGUSSION}

\section{Variations in leaf size indices}

Leaf size indices of the various study sites were measured and the highest average length in leaves was found in elevations ranging $644-651 \mathrm{~m}$ asl and was followed by elevation range $890-892 \mathrm{~m}$ asl (Table 2). The lowest average leaf length was observed at elevation range $1117-1124 \mathrm{~m}$ asl. The highest leaf width was observed at elevation range 890-892 m asl while the lowest was observed at elevation range $1117-1124 \mathrm{~m}$ asl. The biggest leaf area was found in elevation range $890-892 \mathrm{~m}$ asl followed by $644-651 \mathrm{~m}$ asl range. The lowest average leaf area was observed in elevation range $1117-1124 \mathrm{~m}$ asl.

Data collection showed that plants in extremely high elevations had smaller leaf areas (Table 2). The observation supported 
the findings by Kudo et al. (2018) that bamboo leaf size had decreased at very high elevations. In general, plants in mountainous ecosystems showed a decreasing leaf area from the lowest to the highest elevation due to the variations of light, humidity and nutrient (Poorter 2009). Leaf size and other leaf morphological characteristics generally varied with climatic and edaphic conditions and together with altitude and latitude (Box 2012). Pervious research in the tropics showed that with increasing altitudes, leaf size usually decreased from mesophyllous in the lowland to notophyllous in the upper subalpine regions of Mt. Makiling, Philippines (Brown 1919), in New Guinea (Grubb 1974) and Mt. Kerinci, Indonesia (Ohsawa \& Ozaki 1992). The changes in the leaf size from a larger to a smaller size generally followed a gradient from a more favorable habitat to a more stressful environment in the higher altitudes. This pattern was observed not only in large massifs but also in small mountains frequently covered with clouds (Whitmore 1984). Ohsawa (1995) emphasised that the changes in leaf size was also caused by various stress factors other than temperature. Besides environmental conditions, the phytogeographical nature of a locality could influence leaf size zonation.

\section{Variations in culm length, culm diameter, culm thickness, nodes and internodes}

\section{Culm length}

Data on average culm length revealed highly significant difference between culm lengths at different elevations (Table 2). The culms at the lower to mid-elevation range tend to be longer than the culms in higher elevation. The lower to mid-elevation average culm lengths was $25.33 \mathrm{~cm}$ to $29.97 \mathrm{~cm}$ while the highest elevation was only $23.67 \mathrm{~cm}$. The culm lengths at elevation range $890-892 \mathrm{~m}$ asl did not differ statistically with the $344-347 \mathrm{~m}$ asl elevation range. The observation indicated that optimum growth in culms of giant bamboo could reach an elevation up to $900 \mathrm{~m}$ asl. The result might conform to the findings by Li et al. (2014) on the Chimonobambusa utilis where the culm length in mid-elevations was higher than those at the lower elevations implying that the growth was optimal at relatively mid-elevations of Jinfo Mountains in China. Bamboo situated at a high elevation range (1117-1124 $\mathrm{m}$ asl) obtained a lower culm length. A previous report also found that the lower culm lengths were contrasted with more branching and higher culm density

Table 2 Morphological characteristics of giant bamboo across the elevation gradient

\begin{tabular}{lcccccc}
\hline \multirow{2}{*}{ Variables } & \multirow{2}{*}{$\mathrm{F}$} & $344-347$ & $644-651$ & $765-777$ & $890-892$ & $1117-1124$ \\
\cline { 3 - 7 } & $25.123^{* * *}$ & $29.97 \pm 0.06^{\mathrm{a}}$ & $26.57 \pm 0.85^{\mathrm{b}}$ & $25.33 \pm 0.57^{\mathrm{bc}}$ & $29.60 \pm 0.53^{\mathrm{a}}$ & $23.67 \pm 1.76^{\mathrm{c}}$ \\
\hline Culm length & $2.940^{\mathrm{ns}}$ & $74.00 \pm 1.00$ & $80.00 \pm 5.20$ & $78.00 \pm 6.66$ & $73.33 \pm 2.58$ & $68.00 \pm 6.35$ \\
Nodes & $2.940^{\mathrm{ns}}$ & $73.00 \pm 1.00$ & $79.00 \pm 5.20$ & $77.00 \pm 6.66$ & $72.33 \pm 2.58$ & $66.66 \pm 6.35$ \\
Internodes & $3.702^{*}$ & $14.20 \pm 1.65^{\mathrm{bc}}$ & $16.03 \pm 1.05^{\mathrm{ab}}$ & $15.83 \pm 0.76^{\mathrm{ab}}$ & $16.83 \pm 0.76^{\mathrm{a}}$ & $13.57 \pm 1.58^{\mathrm{c}}$ \\
Basal section diameter & $17.905^{* * * *}$ & $4.07 \pm 0.70^{\mathrm{d}}$ & $9.673 \pm 0.58^{\mathrm{c}}$ & $9.77 \pm 0.67^{\mathrm{c}}$ & $15.23 \pm 0.25^{\mathrm{a}}$ & $11.07 \pm 0.11^{\mathrm{b}}$ \\
Mid-section diameter & $17.611^{* *}$ & $2.67 \pm 1.04^{\mathrm{c}}$ & $6.43 \pm 1.40^{\mathrm{ab}}$ & $5.23 \pm 0.25^{\mathrm{b}}$ & $7.95 \pm 1.79^{\mathrm{a}}$ & $5.83 \pm 0.47^{\mathrm{b}}$ \\
Top section diameter & $0.624^{\mathrm{ns}}$ & $25.07 \pm 2.49$ & $26.03 \pm 7.96$ & $23.50 \pm 1.57$ & $25.87 \pm 3.09$ & $20.63 \pm 6.27$ \\
Leaf length & $2.953^{\mathrm{ns}}$ & $3.53 \pm 0.53$ & $3.47 \pm 0.55$ & $3.20 \pm 0.36$ & $3.87 \pm 0.25$ & $2.60 \pm 0.62$ \\
Leaf width & $1.280^{\mathrm{ns}}$ & $59.83 \pm 13.45$ & $62.42 \pm 9.50$ & $50.62 \pm 8.79$ & $67.33 \pm 11.8$ & $37.66 \pm 17.99$ \\
Leaf area & $3.237^{\mathrm{ns}}$ & $7.23 \pm 0.79$ & $7.57 \pm 1.09$ & $8.00 \pm 0.30$ & $8.57 \pm 0.49$ & $7.15 \pm 0.44$ \\
Top section thickness & $4.352^{*}$ & $10.60 \pm 0.71^{\mathrm{ab}}$ & $8.88 \pm 0.75^{\mathrm{b}}$ & $12.03 \pm 1.06^{\mathrm{a}}$ & $11.17 \pm 0.33^{\mathrm{a}}$ & $10.42 \pm 1.38^{\mathrm{ab}}$ \\
Mid-section thickness & $7.497^{* *}$ & $17.83 \pm 0.42^{\mathrm{c}}$ & $25.78 \pm 3.93^{\mathrm{a}}$ & $22.18 \pm 1.81^{\mathrm{ab}}$ & $23.30 \pm 2.76^{\mathrm{a}}$ & $18.353 \pm 3.26^{\mathrm{bc}}$ \\
Basal section thickness & & & & &
\end{tabular}

$\mathrm{df}=10$ in all cases, $\mathrm{F}=$ statistic value; $^{\mathrm{ns}}=$ not significant, $*=\mathrm{p}<0.05, * *=\mathrm{p}<0.01, * * *=\mathrm{p}<0.0001$

Means with the same letter were not significantly different

Means with superscript a is significantly higher than b, c \& d 
as a response to severe conditions in higher elevations (Kudo et al. 2018)

\section{Culm diameter, culm thickness, number of nodes and internodes.}

The average diameter and culm thickness in the basal section diameters among the five elevation gradients showed significant difference (Table 2). The biggest culm diameter in the basal section was recorded at elevation range $890-892 \mathrm{~m}$ asl while the lowest was observed at elevation range $1117-1124 \mathrm{~m}$ asl. The thickest culm was found at elevation range $644-651 \mathrm{~m}$ asl, while the thinnest was at elevation range $344-347 \mathrm{~m}$ asl. A significant difference in culm diameter and culm thickness was also observed for the midsection as the biggest diameter was recorded at elevation range $890-892 \mathrm{~m}$ asl while the smallest diameter was observed at elevation range $344-347 \mathrm{~m}$ asl. The thickest culm was observed at elevation range $765-777 \mathrm{~m}$ asl while the thinnest was observed at elevation range 1117-1124 $\mathrm{m}$ asl. In the top section diameter, results revealed significant difference in the biggest diameter observed at elevation range 890-892 $\mathrm{m}$ asl while the smallest diameter was found at elevation range 344-347 $\mathrm{m}$ asl. Statistical analysis revealed no significant difference for the top section thickness where the thickest culm was observed at elevation range $890-892 \mathrm{~m}$ asl while the thinnest was at elevation range $1117-1124 \mathrm{~m}$ asl. Results from the findings implied that the most ideal site for giant bamboo to obtain a larger diameter and thicker culms should be at an elevation range of $600-900 \mathrm{~m}$ asl. Giant bamboo in the mid-elevation range tended to have thicker culms and larger diameters compared to those that were planted in low $(344-347 \mathrm{~m})$ and high elevation (1117-1124 $\mathrm{m})$. The same observations were also found in Moso bamboo-dominated plantations in Anji and Muchuan provinces in southern China where higher productivity in culms was found in elevations between $500-1000 \mathrm{~m}$ asl range (Mertens et al. 2008). The results of this study contradicted the findings from $\mathrm{Li}$ et al. (2014) which concluded that the basal diameter of $C$. utilis bamboo was significantly high at higher elevations. However, trait responses of plants to elevational gradients were population-specific (Pfennigwerth et al. 2017). C. utilis was dominant species within the altitudinal belt 1300-2200 m while Giant bamboo thrived in the lower-mid elevation range which explained the variation in the response of both species ( $\mathrm{Li}$ et al. 2014). Bamboo culm with the numerous nodes and internodes was also observed at mid-elevation range $644-651 \mathrm{~m}$ asl and at elevation range 765-777 $\mathrm{m}$ asl. The lowest number of nodes was observed at the 1117-1124 $\mathrm{m}$ asl range. The study results revealed seemingly the reduction of the number of nodes and internodes at a higher elevation but analysis showed reduction no significant difference among the five samples (Table 2). Li et al. (2014) reported a pronounced reduction of nodes and internodes from lower to higher elevations for C. utilis. The huge influence of elevation gradient on the morphology of plants was explained by effect of temperature change. The changes were critical to plant growth and development of tissues where they could cause morphological variations such as a decrease in plant size (Jiménez-Noriega et al. 2017). Based on the findings of the study, the reduction was not continuous from the lowest elevation towards the highest. Instead, the reduction was exhibited when the plant exceeded its optimal growth range both in the lower and higher elevation range. Similar to other plants, the sufficient changes in temperature and other abiotic factors such as precipitation, solar radiation and their interactions will determine the productivity of bamboo in a certain region ( $\mathrm{Li}$ et al. 2020).

\section{Nutrient uptake}

The highest nitrogen content was found in the leaf samples collected at elevation range 890-892 $\mathrm{m}$ asl while the lowest was content at elevation range $644-651 \mathrm{~m}$ asl (Figure 2). High nitrogen content was found in low elevation range $344-347 \mathrm{~m}$ asl and the findings did not show a distinct pattern of nitrogen across elevational gradient except for a continuous increase from 644 to $892 \mathrm{~m}$ asl. Leaf nitrogen was known to increase with elevational gradient and thus affecting the plant by increasing the photosynthetic capacity and decreasing $\mathrm{CO}_{2}$ concentrations (Sparks \& Ehleringer 1997). Nitrogen concentration in high elevation 


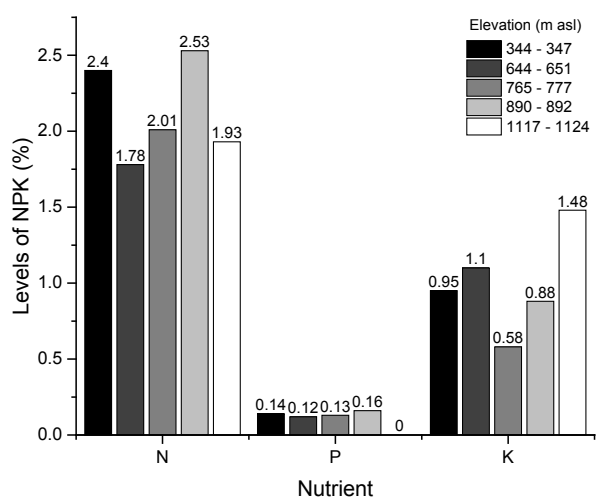

Figure 2 Levels of leaf nitrogen $(\mathrm{N})$, phosphorus $(\mathrm{P})$ and potassium $(\mathrm{K})$ in giant bamboo in various elevation range

areas was a result of high soil nitrogen pools which were accumulated from the reservoir of organic matter slowly decomposing because of the colder temperatures (Bonito et al. 2003).

The highest phosphorus content was obtained from leaf samples in elevation range $890-892 \mathrm{~m}$ asl and followed by the samples from elevation range $344-347 \mathrm{~m}$ asl (Figure 2). However, there was no significant differences for the values in the elevation range from 344-892 $\mathrm{m}$ asl and the samples from elevation range 1117-1124 $\mathrm{m}$ asl were found to be below the detection level. Negative correlations of phosphorus and elevation were reported by Liu et al. (2013) across the entire Loess Plateau region of China. Similar observations were reported in Hawaiian montane forest between elevation range 760-1585 $\mathrm{m}$ asl (Vitousek et al. 1988), tropical montane forest in Ecuador at 1900-3000 m asl elevation range (Soethe et al. 2008) and in mountain ecosystem of southwestern China at $2032-4235 \mathrm{~m}$ asl elevation range (Zhou et al. 2016). The changes in phosphorus content across elevational gradient was similar to nitrogen which was governed by the decreasing decomposition rates of organic matter as temperature decreases in higher elevations and with the influence of vegetation regulating the concentration of phosphorus (Zhou et al. 2016).

The level of potassium was found highest in the samples collected at elevation range 1117-1124 m asl, while the lowest content level was at 765-777 $\mathrm{m}$ asl range (Figure 2). However, it did not show any distinctive pattern or relationship with elevation. The same observation was also noted in leaf

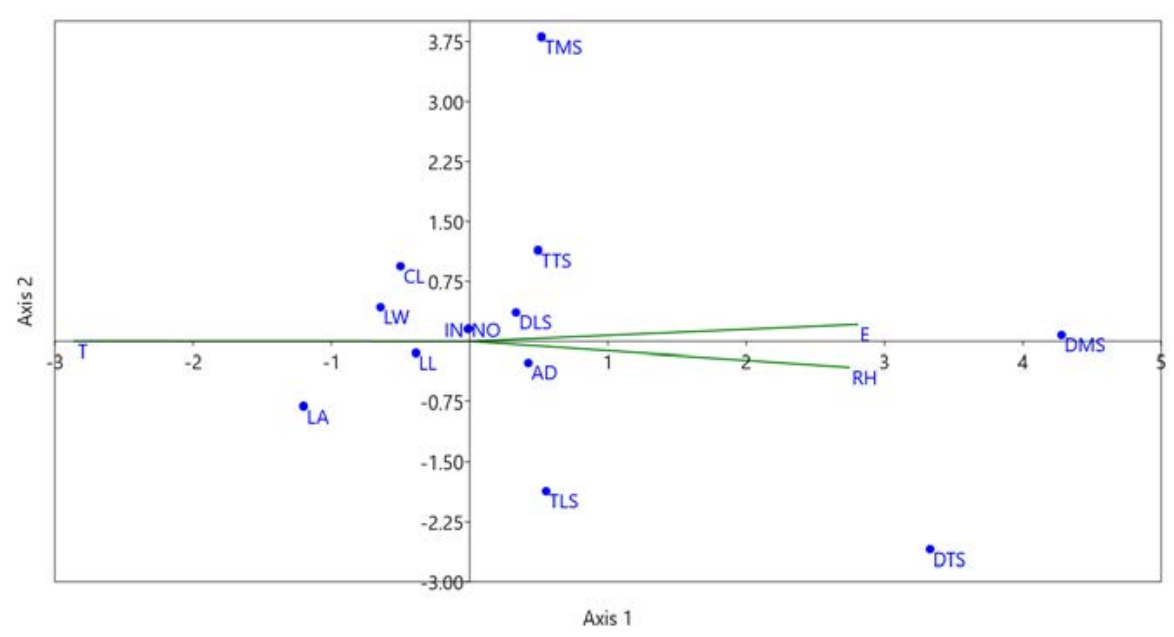

Figure 3 Canonical correspondence analysis of the culm and environmental variables

$\mathrm{E}=$ elevation, $\mathrm{T}=$ temperature, $\mathrm{RH}=$ relative humidity, $\mathrm{CL}=$ culm length,

$\mathrm{NO}=$ nodes, $\mathrm{IN}=$ internodes, $\mathrm{DLS}=$ diameter lower section,

DMS = diameter at the mid-section, DTS = diameter at the top section,

$\mathrm{LL}=$ leaf length, $\mathrm{LW}=$ leaf width, $\mathrm{LA}=$ leaf area,

TTS $=$ thickness at the top section, TMS $=$ thickness at the mid-section,

$\mathrm{TLS}=$ thickness at lower section, $\mathrm{AD}=$ average diameter 
potassium concentration of altitudinal gradients in the mountain ecosystem of Beijing which was explained by the nonlimiting influence of soil to leaf potassium content (Jian et al. 2009). Potassium is an important nutrient in plants that activates specific enzymes during photosynthesis, in respiration and also facilitates internal regulation by osmotic potential and stomatal control (Salisbury \& Ross 1991).

\section{Abiotic effects on plant morphology}

The relationship among variables and its effect on the overall morphological attributes of giant bamboo was depicted through canonical correspondence analysis. Results revealed that both humidity and elevation influenced the diameter and thickness while the temperature seemingly affected the number of internodes, leaf attributes and culm thickness of giant bamboo (Figure 3). Phosphorous and nitrogen had direct effects on the leaf width, area and length while potassium seemingly influenced the number of nodes, internodes, top section diameters and average diameter (Figure 4).
Correlation analysis result showed that the factor of elevation and relative humidity were negatively correlated with the culm length (Table 3). Temperature factor on the other hand was directly correlated with culm length. As elevation and relative humidity increased and temperature decreased along the elevation gradient, bamboo culm length tended to decrease. These observations were also observed in the study by Wen et al. (1999) which found that the culm height and diameter of Bashania spanostachya decreased with increasing elevation gradient. Moreover, the culm length was positively correlated with nitrogen and phosphorous respectively (Table 3). Nitrogen and phosphorous were macroelements and highly needed by plants in large amounts. The increased level of nitrogen and phosphorous had profound effect on the gross morphology of plants which in this case exhibited in culm lengths of giant bamboo. The study by Shanmughavel et al. (1997) on the phosphorous application to Bambusa bambos revealed that high rate of phosphorous and nitrogen supplied to the soil caused bamboo species to increase their ability to store nutrients in their tissues, especially in the culms and the production of wider leaf

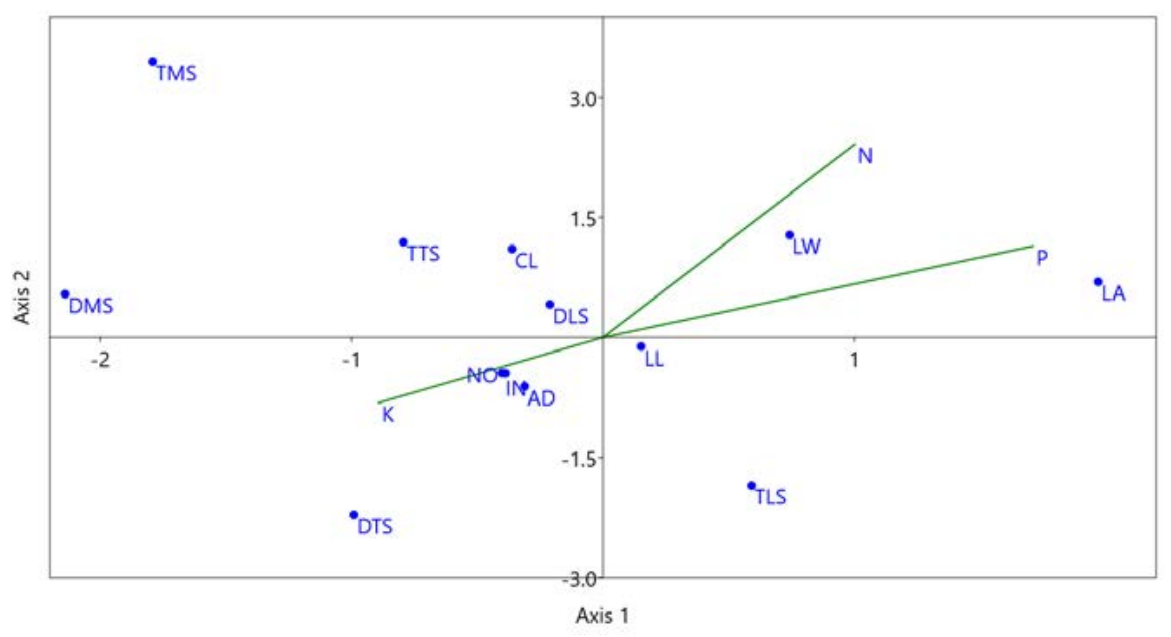

Figure 4 Canonical Correspondence Analysis (CCA) showing the influence of the macroelements to the morphological variations of giant bamboo

$\mathrm{N}=$ nitrogen, $\mathrm{P}$ = phosphorous, $\mathrm{K}=$ potassium, $\mathrm{CL}=$ culm length, $\mathrm{NO}=$ nodes, IN = internodes, DLS = diameter lower section, DMS = diameter at the mid-section, DTS = diameter at the top section, $\mathrm{LL}=$ leaf length, $\mathrm{LW}=$ leaf width, $\mathrm{LA}=$ leaf area, TTS = thickness at the top section, TMS $=$ thickness at the mid-section, TLS $=$ thickness at the basal section, $\mathrm{AD}=$ average diameter 
Table 3 Pearson's R correlation matrix and corresponding p-value between morphological attributes of giant bamboo and abiotic factor

\begin{tabular}{|c|c|c|c|c|c|c|c|c|c|c|c|c|}
\hline Variables & Elev & $\mathrm{p}$-val & Temp & $\mathrm{p}$-val & RH & $\mathrm{p}$-val & $\mathrm{N}$ & $\mathrm{p}$-val & $P$ & $\mathrm{p}$-val & $\mathrm{K}$ & p-val \\
\hline $\begin{array}{l}\text { Culm } \\
\text { length }\end{array}$ & $-0.627 *$ & 0.012 & $0.522 *$ & 0.46 & $-0.646^{*}$ & 0.009 & $0.782 *$ & 0.001 & $0.759 *$ & 0.001 & -0.373 & 0.170 \\
\hline $\begin{array}{l}\text { No. of } \\
\text { nodes }\end{array}$ & -0.401 & 0.139 & 0.363 & 0.184 & -0.313 & 0.257 & -0.188 & 0.502 & 0.492 & 0.063 & -0.462 & 0.083 \\
\hline $\begin{array}{l}\text { No. of } \\
\text { internodes }\end{array}$ & -0.401 & 0.139 & 0.363 & 0.184 & -0.313 & 0.257 & -0.188 & 0.502 & 0.492 & 0.063 & -0.462 & 0.083 \\
\hline $\begin{array}{l}\text { Basal } \\
\text { section } \\
\text { diameter }\end{array}$ & -0.019 & 0.946 & -0.089 & 0.752 & -0.001 & 0.997 & 0.152 & 0.589 & $0.567 *$ & 0.027 & -0.480 & 0.070 \\
\hline $\begin{array}{l}\text { Mid section } \\
\text { diameter }\end{array}$ & $0.770^{*}$ & 0.001 & $-0.852 *$ & 0.000 & $0.743^{*}$ & 0.002 & 0.082 & 0.771 & -0.041 & 0.885 & 0.046 & 0.870 \\
\hline $\begin{array}{l}\text { Top section } \\
\text { diameter }\end{array}$ & $0.596^{*}$ & 0.019 & $-0.677 *$ & 0.006 & $0.648^{*}$ & 0.009 & -0.052 & 0.854 & 0.009 & 0.975 & 0.074 & 0.793 \\
\hline Leaf length & -0.280 & 0.312 & 0.237 & 0.395 & -0.233 & 0.403 & 0.164 & 0.558 & 0.399 & 0.141 & -0.224 & 0.423 \\
\hline Leaf width & -0.393 & 0.147 & 0.306 & 0.267 & -0.379 & 0.163 & 0.465 & 0.081 & $0.688^{*}$ & 0.005 & -0.421 & 0.118 \\
\hline Leaf area & -0.320 & 0.245 & 0.257 & 0.355 & -0.277 & 0.318 & 0.296 & 0.284 & $0.522 *$ & 0.046 & -0.281 & 0.310 \\
\hline $\begin{array}{l}\text { Thickness } \\
\text { top section }\end{array}$ & 0.139 & 0.622 & -0.272 & 0.326 & 0.065 & 0.818 & 0.341 & 0.213 & 0.478 & 0.072 & -0.470 & 0.077 \\
\hline $\begin{array}{l}\text { Thickness } \\
\text { mid section }\end{array}$ & 0.133 & 0.637 & -0.156 & 0.578 & -0.122 & 0.665 & 0.372 & 0.172 & 0.163 & 0.561 & -0.486 & 0.066 \\
\hline $\begin{array}{l}\text { Thickness } \\
\text { lower } \\
\text { section }\end{array}$ & 0.033 & 0.906 & -0.151 & 0.592 & 0.176 & 0.530 & -0.245 & 0.379 & 0.389 & 0.152 & -0.274 & 0.323 \\
\hline $\begin{array}{l}\text { Average } \\
\text { diameter }\end{array}$ & 0.004 & 0.990 & -.133 & .636 & 0.119 & 0.673 & -0.260 & 0.349 & $0.518^{*}$ & 0.048 & -0.485 & 0.067 \\
\hline
\end{tabular}

and bigger leaf area. Similarly, Piouceau et al. (2014) studied the effects of high-nutrient treatment on the seven species of bamboo and found that the increase of phosphorous and nitrogen levels affected the number and length of culms produced whereas the culm diameter was significantly larger than the control. Azmy et al. (2004) reported that the application of phosphorous fertiliser on Gigantochloa scortechinii had increased the culm diameter, height and diameter of bamboo and the number of shoots produced.

The elevation and relative humidity were positively correlated with the mid and top section diameters, indicating that an increase in the mid and top section diameters with the increasing elevation and relative humidity (Table 3). On the other hand, temperature showed a negative correlation with mid and top section diameters, suggesting that a decrease in temperature tended to increase the diameter mid and top section. It was important to note that the increase was relatively found only until at $892 \mathrm{~m}$ asl and a sudden drop in diameter was observed at $1100 \mathrm{~m}$ asl elevation. The observation proposed that the negative correlation was not absolute across elevation gradient and the increase in diameter would not continue beyond its optimal range. The increasing culm dimensions with elevation or altitude gradient were also observed in Moso bamboo propagated in Taiwan resulting in more productive plantations in higher elevations (Chen et al. 2014). However, its productivity was reported to be delimited by elevation as yields of the same bamboo species had decreased beyond $1000 \mathrm{~m}$ asl elevation as observed in southern China (Mertens et al. 2008). The morphological change across elevation gradient and higher productivity in mid-elevations could be explained by photosynthetic activity. The 
concentration of non-structural carbohydrate which was the product of photosynthesis was essential to the growth and adaptation of plants (Körner 2003). Abiotic conditions influenced photosynthetic activity and plant nitrogen concentrations thereby regulating non-structural carbohydrate production. The interplay of factors were expressed in the various ways of partitioning assimilates into structural components in plants (Millard et al. 2007, Qi et al. 2020). The assessment of photosynthetic activity of giant bamboo in varying elevations, therefore should be further assessed in future research.

The result of the non-metric multidimensional scaling (Figure 5) further confirmed that the gross morphology of the giant bamboo was affected by temperature and relative humidity as showed by the culms collected from higher elevation (1117-1124 $\mathrm{m}$ asl) and lower elevation range (344-347 $\mathrm{m}$ asl) and represented by A \& E, respectively. The former study site had lower temperatures and high relative humidity contrary to the latter and both site conditions showed extreme dissimilarity against site $\mathrm{B}, \mathrm{C}$ $\&$ D. In the study, the variation in morphology occured at the lowest and highest elevation while overall similarity was observed at the $600-900 \mathrm{~m}$ asl elevation range indicated by $\mathrm{B}, \mathrm{C}$ and $\mathrm{D}$. The findings implied that the optimum growth for giant bamboo could be achieved at 600-900 $\mathrm{m}$ asl.

\section{CONGLUSIONS}

Results from the experiments confirmed that temperature, relative humidity and elevation had significant effect on the majority of the morphological traits of giant bamboo. There was no significant difference observed on the leaf size indices, eventhough the leaves tended to decrease as elevation increases. However, there was significant difference in terms of culm length, mid-section culm thickness, basal section culm thickness and diameters between the higher and lower elevations but not in nodes and internodes of giant bamboo. The results indicated the most ideal elevation for giant bamboo optimal growth should be at elevations ranging from 600 to $900 \mathrm{~m}$ asl and should be considered as the basis in the selecting giant bamboo planting sites.

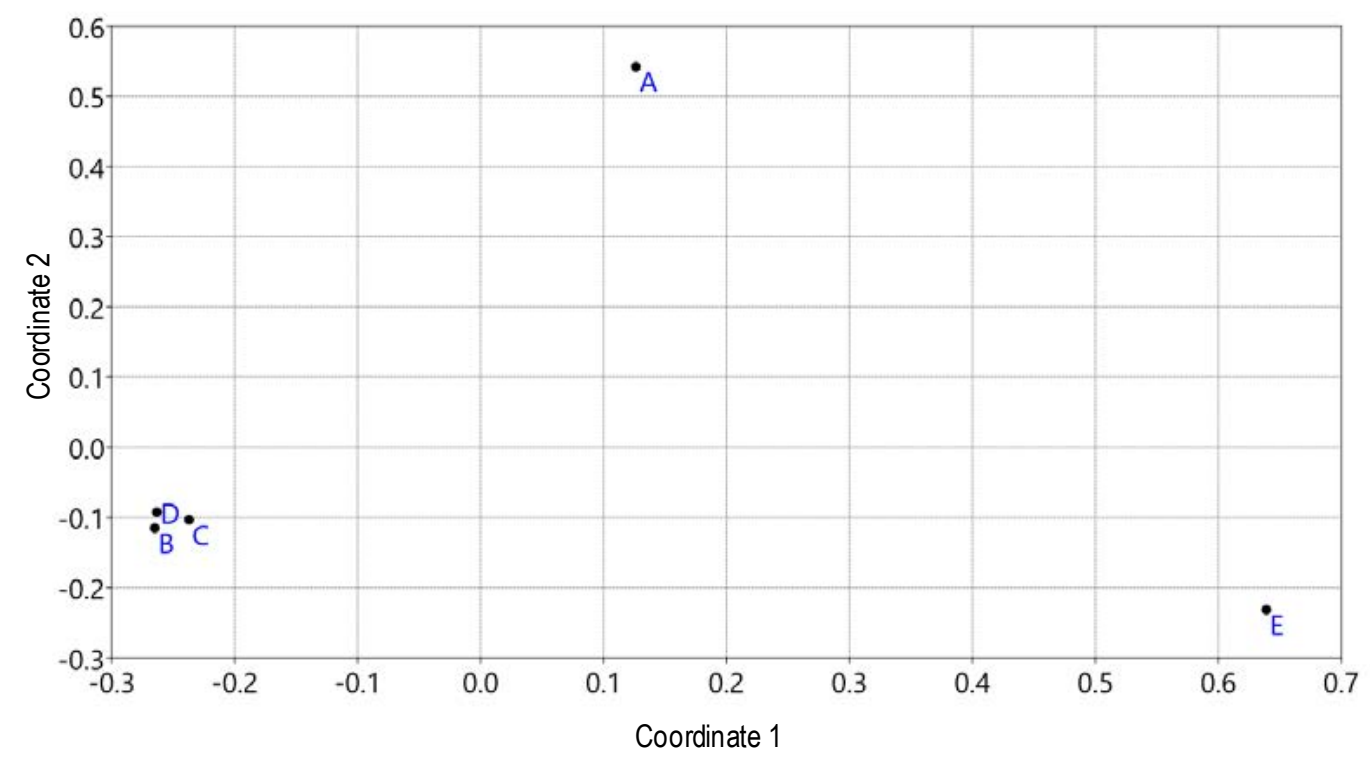

Figure 5 The non-metric multidimensional scaling using Bray-Curtis index to discriminate similarities and differences among the study sites using the environmental variables and culm attributes of giant bamboo

$\mathrm{A}=344-347 \mathrm{~m}$ asl, $\mathrm{B}=644-651 \mathrm{~m}$ asl, $\mathrm{C}=770-777 \mathrm{~m}$ asl, $\mathrm{D}=890-892 \mathrm{~m}$ asl, $\mathrm{E}=1117-1124$ $\mathrm{m}$ asl 


\section{ACKNOWLEDGEMENT}

The authors extended their appreciation to the Philippine Council for Agriculture, Aquatic and Natural Resources Research and Development (PCAARRD), Department of Science and Technology (DOST) for the funding and support in the research project.

\section{REFERENGES}

Aguinsatan RG, Razal RA, Carandang MG et al. 2019. Site influence on the morphological, physical and mechanical properties of giant bamboo (Dendrocalamus asper) in Bukidnon Province, Mindanao, Philippines. Journal of Tropical Forest Science 31: 99-107. https://doi.org/10.26525/ jtfs2019.31.1.099107

Azmy HM, Razak W, Hashim WS et al. 2004. Application of organic fertilisers on natural stand bamboos for sustainable management in Peninsular Malaysia. Journal of Bamboo and Rattan 5: 301-309.

Bonito GM, Coleman DC, Haines BL et al. 2003. Can nitrogen budgets explain differences in soil nitrogen mineralization rates of forest stands along an elevation gradient? Forest Ecology and Management 176: 563-574. https://doi. org/10.1016/S0378-1127(02)00234-7

Box EE. 2012. Macroclimate and Plant Forms: An Introduction to Predictive Modeling in Phytogeography. Springer Science \& Business Media, Dordrecht.

Brown WH. 1919. Vegetation of Philippine Mountains: The Relation Between the Environment and Physical Types at Different Altitudes (No. 13). Bureau of printing, Philippines.

CaIn SA \& DE CASTro GM. 1959. Manual of Vegetation Analysis. Harper, New York.

Chen TH, Chiu CY, XIE ZY et AL. 2014. Growth characteristics of Moso Bamboo (Phyllostachys pubescens) plantations at various altitudes-for instance in Daan Area, Nantou County. Quarterly Journal of China Forestry 47: 181-192.

Decipulo MS, Ockerby S \& Midmore DJ. 2009. Managing clumps of Dendrocalamus asper in Bukidnon, Philippines. Pp 36-45 in Midmore DJ (ed) Silvicultural Management of Bamboo in the Philippines and Australia for Shoots and Timber. Proceedings ACIAR workshop. 22-23 November 2006, Philippines.

Gratani L. 2014. Plant phenotypic plasticity in response to environmental factors. Advance Botany 2014: 1-17. https://doi.org/10.1155/2014/208747

GRUBB PJ. 1974. Factors controlling the distribution of forest-types on tropical mountains: new facts and a new perspective. Altitudinal zonation in Malesia 16: 1-25.

Jian Q, Keming M, \& Yuxin Z. 2009. Leaf-trait relationships of Quercus liaotungensis along an altitudinal gradient in Dongling Mountain, Beijing. Ecological Research 24: 1243-1250. https://doi. org/10.1007/s11284-009-0608-3
Jiménez-Noriega PMS, Terrazas T, López-Mata L et aL. 2017. Anatomical variation of five plant species along an elevation gradient in Mexico City basin within the Trans-Mexican Volcanic Belt, Mexico. Journal of Mountain Science 14: 2182-2199. https:/ / doi.org/10.1007/s11629-017-4442-8

KörNER C. 2003. Carbon limitation in trees. Journal of ecology 91: 4-17. https://doi.org/10.1046/j.13652745.2003.00742.x

Kudo G, Aoshima Y, Miyata R et al. 2018. Altered morphologies and physiological compensation in a rapidly expanding dwarf bamboo in alpine ecosystems. Arctic, Antarctic, and Alpine Research 50: 1-11. https://doi.org/10.1080/15230430.2018.1 463733

Li QY, Zhang ZW, TAo JP et aL. 2014. Effect of elevation and canopy condition on morphological traits and leaf fluctuating asymmetry of a bamboo, Chimonobambusa utilis in Jinfo Mountain Nature Reserve, Southwest China. Sains Malaysiana 43: $1119-1125$.

Li X, Du H, Mao F et al. 2020. Mapping spatiotemporal decisions for sustainable productivity of bamboo forest land. Land Degradation E Development 31: 939-958. https://doi.org/10.1002/ldr.3509

LiU ZP, SHAO MA \& WANG YQ. 2013. Spatial patterns of soil total nitrogen and soil total phosphorus across the entire Loess Plateau region of China. Geoderma 197-198: 67-78. https://doi. org/10.1016/j.geoderma.2012.12.011

Mertens B, Hua L, Belcher B et al. 2008. Spatial patterns and processes of bamboo expansion in Southern China. Applied Geography 28: 16-31. https://doi. org/10.1016/j.apgeog.2007.07.012

Midmore DJ. 2009. Silvicultural management of bamboo in the Philippines and Australia for shoots and timber. Proceedings ACIAR workshop. 22-23 November 2006, Philippines.

Millard P, Sommerkorn M \& Grelet GA. 2007. Environmental change and carbon limitation in trees: a biochemical, ecophysiological and ecosystem appraisal. New Phytologists 175: 11-28. https://doi.org/10.1111/j.14698137.2007.02079.x

Mooney KA \& Agrawal AA. 2008. Phenotypic plasticity in plant-herbivore interactions. Pp 43-59 in Tilmon $\mathrm{K}$ (ed) Specialization, speciation, and radiation: the evolutionary biology of herbivorous insects. University of California Press, London England.

OHSAWA M. 1995. Latitudinal comparison of altitudinal changes in forest structure, leaf-type, and species richness in humid monsoon Asia. Vegetation 121: 3-10. https://doi.org/10.1007/978-94-011-0343$5 \_1$

Ohsawa M. \& Ozaki K. 1992. Hierarchical analysis of vegetation/environment pattern for east Asian extra-tropical evergreen broad-leaved forests. Journal of Japan Biometeoreology 29: 93-103.

Parlucha J, Barbadillo N \& Sedenio P. 2017. Speciessite matching based on growth performance evaluation of mixed native and exotic secondary forest in Musuan Bukidnon. Journal of Biodiversity and Environmental Science 10: 62-70. 
Pfennigwerth AA, Bailey JK \& Schweitzer JA. 2017. Trait variation along elevation gradients in a dominant woody shrub is population-specific and driven by plasticity. AoB PLANTS 9: 13 pages. https://doi. org/10.1093/aobpla/plx027

Piouceau J, Bois G, Panfili F et al. 2014. Effects of high nutrient supply on the growth of seven bamboo species. International Journal of Phytoremediation 16: 1042-1057. https://doi.org/10.1080/15226514. 2013.810583

Pond AP, Walworth JL, Kilby MW et AL. 2006. Leaf nutrient levels for pecans. Hort Science 41: 1339-1341. https://doi.org/10.21273/ HORTSCI.41.5.1339

Poorter L. 2009. Leaf traits show different relationships with shade tolerance in moist versus dry tropical forests. New Phytologists 181: 890-900. https:/ / doi. org/10.1111/j.1469-8137.2008.02715.x

Pulhin JM \& Ramirez MAM. 2016. Timber regulation and value chain in community-based timber enterprise and smallholder forestry in the Philippines. Forests 7: 152. https://doi.org/10.3390/f7080152

Qi J, Liu W, Jiao T \& Hamblin A. 2020. Variation in morphological and physiological characteristics of wild Elymus nutans ecotypes from different altitudes in the northeastern Tibetan Plateau. Journal of Sensors 2020: 11pages. https://doi. org $/ 10.1155 / 2020 / 2869030$

Razal RA \& PALjon AM. 2009. Non-Wood Forest Products of the Philippines. UPLB College of Forestry and Natural Resources, Philippines.
Salisbury FB \& Ross CW. 1991. Plant physiology. Washington Publishing, Belmont.

Shanmughavel P, Francis K \& George M. 1997. Plantation Bamboo. International Book Distributors, India.

Soethe N, Lehmann J \& Engels C. 2008. Nutrient availability at different altitudes in a tropical montane forest in Ecuador. Journal of Tropical Ecology 24: 397-406. https://doi.org/10.1017/ S026646740800504X

SPARKS JP \& EhlERINGER JR. 1997. Leaf carbon isotope discrimination and nitrogen content for riparian trees along elevational transects. Oecologia 109: 362-367. https://doi.org/10.1007/ s004420050094

Vitousek PM, Matson PA \& Turner DR. 1988. Elevational and age gradients in Hawaiian montane rainforest - foliar and soil nutrients. Oecologia 77: 565-570. https://doi.org/10.1007/BF00377275

Wen WF, Jian FZ, Wang WZ et al. 1999. Association between environmental factors and growth of bamboo species, Bashania spanostachya, the food of giant and red pandas. Acta Ecological Sinica 5: 27-39.

Whitmore TC. 1984. Tropical Rainforest of the Far East. Clarendon Press, Oxford.

Zhou J, Wu Y, Bing H et aL. 2016 Variations in soil phosphorus biogeochemistry across six vegetation types along an altitudinal gradient in southwest China. Catena 142: 102-111. https:// doi.org/10.1016/j.catena.2016.03.004 